\title{
About the main requirements of eloquence speech
}

\author{
Otkur Islamov \\ Candidate of philological sciences \\ Uzbek State Institute of Arts and Culture \\ Head of "Uzbek language and literature" department
}

\begin{abstract}
This article is a scientific analysis of Alisher Navoi's views on speech culture and communication etiquette, and the author has tried to summarize all the views expressed in this area. That is, based on the observation of Alisher Navoi's views on the qualities of good speech in his works, he proved with examples that the meaning of the word "fasohat" (eloquence) (فصاحت) is closer to the concept of speech culture, language culture.

Keywords: language, word, speech, speech culture, speech etiquette, communication etiquette, cultural speech, eloquence, eloquence speech, correct pronunciation, linguistic, meaning, meaningful word, deep meaning.
\end{abstract}

\section{Introduction}

In the history of our millennial culture, there are countless masterpieces of fine art, which are the product of the artistic genius of our people. Many of them, as magnificent monuments of the depth of Turkish thought and the infinity of imagination, are snowing in the net of the ganjina of world art [3, P.25].

Eloquent speech means following the rules of correct pronunciation, having a sound and tone appropriate to meaningful speech and expression. All of these are calls for people to master the language perfectly, to use it correctly and effectively, to direct speech to noble goals.

Alisher Navoi, speaking of eloquent speech, paid great attention to the pronunciation, sound and tone acceptability, which is the means and form of its emergence, and stressed that they should correspond to the purpose and function of speech. Navoi repeatedly stressed the importance of pronunciation of words, the tone of speech. The point is that clear pronunciation serves to say words in full form, especially to distinguish words in homonymous and paronymic form according to their meaning, so that the listener can quickly understand such words. Also, a clear, accurate pronunciation, soft, gentle tone, rhetorical, uplifting tone in the right places attracts the attention of the listener, and even fascinates him when reading works of art. Therefore, in the pages of his works, Navoi focused on the issue of pronunciation and melody.

\section{Main part}

In the "Explanatory Dictionary of Alisher Navoi's works" the word fasohat (فصاحت) is interpreted as follows: fasohat (فصاحت) - the word is open, clear, beautiful and in accordance with the rules [2, p.335]. In another dictionary, it is written that the notion of the beauty of style is pleasing. (Dictionary of Navoi Works, p. 636). The definitions of the word fasohat (فصاحت) have certain differences. For example, in "Farhangi zaboni tochiki" fasohat (فصاحت) is interpreted as a burr of language, clarification of thought, narration [4, p.425]. The authors used the word sukhan (سخن) to give this explanation. Sukhan (سخن) means speech, word [4. p.232]. However, in the interpretation of the word sukhan (سخن), in addition to the meaning of the word, it is also correct to interpret it as a speech, $a$ conversation [1, p.89].

In the "Explanatory dictionary of the Uzbek language" the word fasohat (فصاحت) is interpreted as follows: "The ability to speak beautifully and pleasantly, the clarity and fluency of speech" [5, p.334].

Based on the observation of Alisher Navoi's views on the qualities of good speech, we understand that the meaning of the word eloquence (فصاحت) is closer to the concept of speech culture, language culture.

Alisher Navoi spoke extensively about the positive factors that give rise to eloquent speech and paid special attention to linguistic factors. These are:

1. Speech should be colorful and rich in expressions. One of the positive features of speech is being expressive. A good, expressive word has a positive effect on the listener when he hears it. Navoi expresses this concept in the word puberty (بلاغت كوش): 
Демонки, сўз айтурва балогаткйш ўл,

Нафсингzа салох истар эсанг хомўш ўл.

("Nazm ul-javohir", p.158;

"Explanatory Dictionary of the Language of Alisher Navoi's Works", Volume I, page 208)

The diversity of speech requires the use of linguistic means in it. In diversity, the poet considers both the content of the speech and the colorful linguistic means of expressing it. This means that speech should be colorful in both content and form.

\section{Борчасининг нуктаси рангин эрур,}

Назмлари дилкашу ширин эрур. (“Hayrat ul-abror ”, p.66)

Word use varies according to speech style and genres. According to Navoi, the use of the word in poetic and prose speech differs:

Назм анга гулианда очилмовливи,

Наср құро ерга сочилмоглиги. (“Hayrat ul-abror”,p. 61)

The poet does not appreciate a poem written without meaning, that is, those who do not have a deep understanding of the meaning of the word. He evaluates their works in the eyes of the people:

Назмки маъни анга марвуб эмас,

Ахули маоний қуошида хўб эмас. (“Hayrat ul-abror”, p.62)

2. It is better to pay attention to the language, to think and speak thoughtfully. According to Navoi, a person should pay attention to his language and thoughts. It is good that the speech did not contain conjecture, ambiguity, vague messages. This undermines the authenticity of the speech:

Эл хуар не такаллум этса билмай,

Ўз суззини дави фахмм қълмай. ("Layli and Majnun”, p.150)

While the great writer spoke of being attentive to language, this notion interpreted demand in the following words:

Til hifzi (تيل حفظى) - careful approach to language, speaking according to need:

Инсон ани билки, ком эрур онга салох,

Тил хифзидадур зумраи инсонва салоху.

("Nazm ul-javohir", page 159; "Explanatory Dictionary of the Language of Alisher Navoi's

Works", Volume III, page 229)

Dottedness (نكته دان ليق) subtle insight, deep thinking:

Неча изхор ажзу нотовонлиқ,

Гумон қ̧илдинг бу ишни нуктадонлиқ.

("Vaqfiya", p. 251)

3. It is necessary to know and master the language at the required level of its rich potential. Alisher Navoi, while evaluating the speech of some individuals, determines their linguistic skills according to the extent to which they have mastered the riches of the language and the extent to which they use it: "Sahl b Abdullah Tustariy. ... Kuniyati Abu Muhammad. They are strong in condition and weak in words". (“Насойим ул-мухаббат”, 54-бет). The poet is making such assessments used definitions such as biyik kalim, buyuk kalom, yahshi tilda adosi bor, furun va nuqtada barkamol, nadim sheva, shiringoy. For example: "Abu Bakr Tamastani. It is the fifth layer. Love overcame him and he had a great word and code". ("Nasayim ul-muhabbat", p. 134) and others.

4. It is necessary to choose the means from the language that correspond to the idea to be expressed in the speech and to use them in accordance with the linguistic features and rules of the language. "The correct expression of the structure and structure of thought can be said to be the basis of the logic of speech" [3.p.116]. Alisher Navoi believes that a person who is fluent in the language should be able to adapt to the content of speech, to express ideas correctly and to choose and use appropriate language tools, following the rules of language. Eloquent speech should be in accordance with the rules of language: 
Ул бири ул фазлу фасохат била,

Бу бири бу феълу қ̧абохฺат била. page 219

("Hayrat ul abror",

"Explanatory Dictionary of the Language of Alisher Navoi's Works", Volume III, page 335)

In this regard, Navoi describes the speech of King Garib Mirza, son of Hussein Boykaro:

Қаю шахзода ул кони малохуат,
Такаллум вақти дарёйи фасохқат.

(Qayu prince is a source of beauty

In the time of price like a river of eloquence ) ("Farhod and Shirin, "p. 461)

The linguistic means chosen in the speech should correspond to the subject, the requirement of the speech style. Navoi expressed this demand on the basis of emphasizing the specificity of the language of poetry and prose:

Наср аро элга худ мақуолат бор,

Лек назм ичра ўзга хуолат бор.

(There is an article in the prose

There is a different situation in poetry) ("Sab'ai Sayyar", page 36)

5. In speech, it is appropriate to use elegant words as required by the idea. Navoi writes that it is necessary to use subtle, elegant and touching words in speech and to express deep, profound thoughts through them. The following words used in the poet's works are used in connection with such a delicate and elegant definition of speech:

Fine dialect (نازوك شيوه)- subtle words: "Mawlana Muhammad Amili was a gentleman and said subtle words". ("Majolis un-nafois ", p.54)

In "Nasayim ul-Muhabbat" and "Majlis un-nafois", some people evaluate their speech according to the stated requirement: "Abulqasim Hakim Samarkandiy q.t.s. His name is Ishaq ibn Muhammad Ismail. Abu Bakr spoke with Warraq. He has good words. In dealing and in the unseen of lust and in the calamity of deeds". ("Nasayim ul-muhabbat", p. 87); "At that moment, I turned the pen into a diamond with the zikr on the face". ("Nasayim ul-muhabbat", p.480)

Nuqtapardozlig(نكته يردازليغ) - Ability to say deeply meaningful words: "This kind of attention and punctuation of the humoyun tab will not be completed for years to come.". ("Majlis un-nafois ", page 210; "Explanatory Dictionary of the Language of Alisher Navoi's Works", Volume II, page 489) Navoi believes that the use of elegant words in speech is equally appropriate for both speaking and writing:

Homai durbor(خامة دوربار) - delicate, elegant words writer pen: "He is the one whose pearls have made this name a pearl, and he is the one whose pearls have been scattered from his crown.". ("Nazm ul-javohir ", p. 129; "Explanatory Dictionary of the Language of Alisher Navoi's Works", Volume II, page 410)

Navoi describes the words of Khusrav Parvez's minister Buzurg Ummid to Mehinbonu as follows:

Садафдек чунки овзин очқ̧ай охир,

Хадис ўрнива гавхар сочқай охир.

(Like a pearl because the mouth is open at the end

The hadith is replaced by a pearl ) ("Farhod and Shirin, ”p. 287)

Eloquent speech should follow the rules of pronunciation, the speech should have a sound, tone appropriate to the content and expression. It should be noted that the purity of a person's speech is one of the indicators of his spiritual-enlightenment, linguistic-cultural level.

Alisher Navoi, speaking of eloquent speech, paid great attention to the acceptability of pronunciation, sound and tone, which is the means and form of its emergence, and stressed that they 
should correspond to the purpose and function of speech, and repeated these criteria. The point is that clear pronunciation helps to pronounce words in full form, especially to distinguish words in homonymous and paronymic forms according to their meaning, so that the listener can quickly understand such words. Also, a clear, accurate pronunciation, soft, gentle, and where appropriate, rhetorical, uplifting tone will capture the listener's attention and even captivate him. For this reason, Navoi in the pages of his works has focused on the issues of pronunciation and melody. To confirm this idea, we cite words and phrases that express the concepts of pronunciation and tone:

Pronunciation (تلفظ) - In Navoi's works, the word means to speak, to tell, to say: "And every "to" is still silent, if it falls in the middle of the byte and enters the pronunciation, each of them enters into by knowing his nickname.". ("Mezon ul-avzon ", page 61; "Explanatory Dictionary of the Language of Alisher Navoi's Works", Volume III, page 171)

$\operatorname{Ado}(ا د)$ - in the sense of pronunciation, meaning, word, phrase:

"...I can't translate this book into Turkish and I can solve this problem more clearly? - I thought". ("Nasayim ul-muhabbat", p. 12). "He had a good tongue in this science." (Nasayim ul-muhabbat, p. 164)

Anfos (انفاس) - one of the meanings of this word is sound, tone, speech:

Худхуд анфоси шакаррез айлади,

Ул шакарни нуктаомез айлади.

(Hudhud sound turned into sugarcane

He turned the sugar into a dot ("Lison ut-tayr", page 35;

"Explanatory Dictionary of the Language of Alisher Navoi's Works", Volume I, page 103)

Navoi believes that one of the factors that enhances the effectiveness of speech and gives it beauty is the beautiful pronunciation of words and sentences. This view is reflected in the author's poems about Nizami:

Қойили хуш каломи зебогўй,

Ки, бу майдон элидин элитти гуй.

(His beautiful words are beautiful

(He was from people of this area) ("Sab'ai Sayyar", page 36;

"Explanatory Dictionary of the Language of Alisher Navoi's Works", Volume I, page

The author describes Dilorom in the epic "Sab'ai Sayyar" and praises her language and eloquence as follows:

Лаби суиз дерда элдин олиб жон,

Лабларин чун куируб уёлиб жон.

(The word lip is a pain in the heart

I'm ashamed to see your lips ) ("Sab'ai Sayyar, p.97)

Mahraj (مخرج) - pronunciation, the current term - articulation: "May the souls of the Muslims be at peace and enjoy themselves.". ("Mahbub ul-qulub ", p.29; "Explanatory Dictionary of the Language of Alisher Navoi's Works", Volume II, page 263)

Navoi believes that in the process of speech it is necessary to choose polite words, to pronounce politely:

Ани истаб яна құошива доим,

Вафо омиз суизлар деб мулойим.

(Always on the brow again wanting it

The words of the faithful are gentle ) ("Farhod and Shirin, "p. 308)

Un(اون)- sound, tone: "Sha'vona. He was from Ajam and used to sit with Ubullah. And it was good that he was there and he was preaching knowingly". ("Nasaiym ul-muhabbat ", p.484); "The sheikh became famous and unstable in heaven." ("Nasaim ul-muhabbat", p.165); "One of Khoja's perfections was the memorization of Qur'an and the 
science of recitation.". ("Majolis un-nafois ", p.164); "Muhammad Ali ... loved him and his method". ("Majlis un-nafois ", page 66; "Explanatory Dictionary of the Language of Alisher Navoi's Works", Volume III, page 293)

Kindness (حوش آوازليغ ) - possessing a pleasant, beautiful voice: "Mutahhari Udiykim could be the father of Zuhra in kindness and the guardian of her child in kindness.". ("Khamsat ul-mutakhayirin, p. 17; "Explanatory Dictionary of the Language of Alisher Navoi's Works", Volume III, page 442)

Khushkhan (حوشخان) - a pleasant (impressive) reader; singer:

Чекти булбул киби минг лахун ила достон хуофиз,

Йўқанингдек яна бу даврда хушхон хуофиз.(“"Navodir ush-shabab, p. 208; "Explanatory Dictionary of the Language of Alisher Navoi's Works", Volume I, page 444)

"And because it is more pleasant than most of them". ("Holoti Pahlavon Muhammad ", page 106; "Explanatory Dictionary of the Language of Alisher Navoi's Works", Volume III, page 444); "Mawlana Qudsi is greed, a sweet man. "(Majlis un-nafois, p. 20); "Mavlono Badahshi - a noble man, in the time of Ulugbek Mirzo in Samarkand the poet was kindly accepted as a Muslim". ("Majlis un nafois ", page 24); "Mavlono Kavsari is from Bukhara. He was a man of ability, eloquence, and a wise man.". ("Majlis un-nafois", page 55)

In his works, Navoi not only promotes the positive qualities of speech culture and etiquette, but also focuses on the factors and factors that violate the culture and etiquette of speech. He could not stay out of the matter. Because during the Navoi period, oratory was widely developed. Among the people were skilled orators.

Second, Navoi saw the issue of speech culture and etiquette as one of the main factors that provided art in many places. In his works, the issues of artistic culture and morality are described and studied in detail. Therefore, Navoi's comments on the culture and etiquette of speech apply not only to ordinary speech, the art of oratory, but also to the requirements of artistic language, art.

6. Speech should be powerful enough to influence the listener. To do this, the words must come from the heart: "... this chemical work is a testament to the grace of God". ("Nasaim ul-muhabbat ", p. 12; "Explanatory Dictionary of the Language of Alisher Navoi's Works", p. 140) The poet evaluates the words of some speakers and celebrities in terms of their power. "Abu Nasr Nujayd, his word, by default, is more effective than words and reaches quickly". ("Nasayim ul-muhabbat", p.159); "Mevlana Muhyi, and he is the modern preacher". ("Nasayim ul-muhabbat", p.436); "Xoja Muayyad Mehna, his breath in the sermon is very effective, his actions in the sky are very effective". ("Nasayim ul-muhabbat", p.442)

The sharpness and expressiveness of the speech can be so great that it melts even the stone, as Navoi has repeatedly said in his works. For example, when the person who brought the news of Majun's arrival to Layli heard his speech, all the grief in his heart, in Navoi's language, dissipated, that is, it melted:

Лайли чу анинг сўзин эщитти,

Кўнгли темурин дами эритти.

(Layli heart his words

And melted even iron heart) ("Layli and Majnun, "p192)

\section{Conclusion}

Hence, the notion of the etiquette and culture of speech, the considerations of the requirements and norms of exemplary, eloquent speech, has an ancient history. But in the past, our ancestors understood the culture of speech mainly as a speech etiquette and considered it as one of the means of educating a person whose speech morality is perfect in all respects. The main criteria of speech etiquette were considered to be kind words, truthful words, honesty, meaningful and beautiful, effective speech.

\section{References}


* Annotated dictionary of the language of Alisher Navoi's works. Volume IV. Volume II. Tashkent. Fan. 1983. 644 p.

* Annotated dictionary of the language of Alisher Navoi's works. Volume IV. Volume III. Tashkent. Fan. 1983. 644 p.

* Mahmudov N. Teacher speech culture. Tashkent .: Alisher Navoi National Library of Uzbekistan Publishing House. 2007. 188 p.

* Farhangi zaboni tochiki II tom, 425-p.

* Annotated dictionary of the Uzbek language, Vtomlik, Volume IV, Tashkent. State Scientific Publishing House "National Encyclopedia of Uzbekistan". 2008. 608 p. 